\title{
University Reputation: Scale Development and Validation
}

\author{
E. Eser Telci* \\ Istanbul Bilgi University
}

\author{
Deniz Kantur** \\ Istanbul Bilgi University
}

\begin{abstract}
The hyper-competitive environment and the prominence of the stakeholder perspective force today's organizations to properly manage their reputation status. The importance of reputation for universities and higher academic institutions as a strategic intangible asset has also risen in the last two decades. Even though there are studies in the literature that attempt to develop measures of university or academic institution reputation, they are in their early stages. The current study attempts to develop a scale that measures university reputation by adopting both qualitative and quantitative methodologies. First, scale items are generated through in-depth interviews conducted with multiple stakeholders. Next, building on the relevant literature and through pre-testing the items, the university reputation scale is developed and validated by confirmatory factor analysis. The results show that university reputation is a multidimensional construct with three dimensions: academic competence, responsible management and social attractiveness. The scale developed in the current study attempts to add to university reputation literature by enabling both academicians and practitioners to assess the reputation of differing universities.
\end{abstract}

Keywords: university reputation, corporate reputation, academic competence, scale development, confirmatory factor analysis.

\section{Üniversite İtibarı: Ölçek Geliştirme ve Geçerleme}

\section{Özet}

Hızla değişen çevre koşulları ve paydaş anlayışının artan önemi, günümüz işletmelerini itibarlarını etkili bir biçimde yönetmeye zorlamaktadır. Son yirmi yılda, maddi olmayan bir varlık olarak itibarın önemi üniversiteler ve yükseköğretim kurumları için giderek artmaktadır. Yazında üniversite itibarını ölçmek amacıyla ölçek geliştirmeyi içeren çalışmalar olsa da, yazının henüz gelişiminin çok başında olduğu söylenebilir. Bu çalışma, nitel ve nicel yöntemler kullanarak üniversite itibar ölçeği geliştirmeyi hedeflemektedir. İlk olarak, ölçek öğelerini geliştirmek amacıyla farklı paydaşlarla derinlemesine mülakatlar yapılmışırı. Sonrasında, şu an ki yazın ve geliştirilen öğelerin önceden test edilmesiyle üniversite itibar ölçeği geliştirilmiş ve doğrulayıcı faktör analizi ile geçerlenmiştir. Sonuçlara göre, üniversite itibarı çok boyutlu bir kavram olarak akademik yetkinlik, sorumlu yöne-

\footnotetext{
* E. Eser Telci is an Assistant Professor in the Department of Management at İstanbul Bilgi University, 34060, İstanbul Turkey. E-mail: eser.telci@bilgi.edu.tr

** Deniz Kantur is an Assistant Professor in the Department of Management at İstanbul Bilgi University, 34060, İstanbul Turkey. E-mail: deniz.kantur@bilgi.edu.tr
} 
tim, sosyal çekicilik boyutlarıyla kavramsallaştırılmıştır. Bu çalışmada geliştirilen ölçek üniversite itibarı yazınının gelişimine katkıda bulunmayı ayrıca hem akademisyen hem de uygulayıcılara farklı üniversitelerin itibarını ölçme olanağı sağlamayı hedeflemektedir.

Anahtar kelimeler: üniversite itibarı, kurumsal itibar, akademik yetkinlik, ölçek geliştirme, doğrulayıcı faktör analizi.

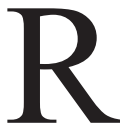

eputation has been a serious concern for both organizations and academia during the last half decade. There is strong evidence confirming the importance of reputation in the development of a sustainable competitive advantage (e.g., Gotsi and Wilson, 2001; Gardberg and Fombrun, 2002; Roberts and Dowling, 2002). According to Kay (1993), reputation has a significant role in achieving organizational success. Hall (1993) invites managers to give greater and continuous attention to reputation since it is considered the most important intangible asset of an organization. Abimbola and Vallaester (2007) stress the fact that reputation becomes even more vital in highly competitive markets.

While reputation research mostly focuses on for-profit organizations, non-profit organizations (hereafter, NPOs) are operating in a competitive environment as well, and this situation forces them to focus more on their reputation as a strategic intangible asset that influences their success (Venable et al., 2005; Weerawardena and Mort, 2008; Sarstedt and Schloderer, 2010). Previous research shows that reputation plays a prominent role in the non-profit sector enabling long-term funding (Smith and Shen, 1996; Brown and Slivinski, 2006), generating support from corporations (Galaskiewicz and Colman, 2006), and attracting volunteers and high-quality staff (Leete, 2006).

With a similar rationale, the importance of reputation, image, and identity concepts in educational services also gained renewed attention especially after the 2000s (Kazoleas et al., 2001; Nguyen and LeBlanc, 2001; Melewar and Akel, 2005; Ressler and Abratt, 2009; Sung and Yang, 2009; Brewer and Zhao, 2010; Aula and Tienari, 2011; Fares et al., 2013; Steiner et al., 2013). With increased competition in the education industry, creating a sustainable competitive advantage through providing qualified service has become more and more important, especially for universities. There has been a huge expansion globally in the higher education industry in the past two decades (Bowman and Bastedo, 2010) forcing universities to actively manage their reputational status (Ressler and Abratt, 2009). In the national context where this study is conducted, there has been a massive increase in the number of universities as well. According to YOK (2012), the number of universities in Turkey was 77 in 2005 and this number increased to 178 as of March 2013. While this increase is necessary considering the size of the young population in the country, the rapid increase may lead to quality concerns that increase the importance of quality and reputation perceptions of stakeholders.

Considering that the quality of service provided by a university is primarily based on the perceptions of quality from the point of view of both internal and external stakeholders (Alessandri et al., 2006), the studies in the literature have concentrated on the image, identity, and reputation management practices of universities (Theus, 1993; Nguyen and LeBlanc, 2001; Alessandri et al., 2006; Sung and Yang, 2008; Sung and Yang, 2009; 
Brewer and Zhao, 2010; Aula and Tienari, 2011). While there are studies concentrating on the concept of reputation for universities (Theus, 1993; Lowry and Silver, 1996; Nguyen and LeBlanc, 2001; Alessandri et al., 2006; Sung and Yang, 2008; Yang et al., 2008; Ressler and Abratt, 2009; Steiner et al., 2013), there is still a gap in the literature regarding the conceptualization of the university reputation construct and thus more empirical studies are needed. Ressler and Abratt (2009), pointing to the fragmented pattern of university reputation literature, suggest that different stakeholder perceptions are crucial in constructing university reputation. This research attempts to fill this gap through an in-depth analysis of the construct from multiple stakeholder perspectives. Although some studies (Alessandri et al., 2006; Sung and Yang, 2009; Oktar and Çarıkç1, 2012; Fares et al., 2013) adopt versions of the reliable and valid scales of corporate reputation in the literature (Fombrun and Van Riel, 1997; Fombrun et al., 2000), more qualitative research and further purification and refinement are essential to arrive at a more concrete operationalization of the construct in the university context. Thus, this paper aims to contribute to the literature through developing a measurement approach for university reputation. The development of a valid and reliable scale is necessary for more quantitative studies in the available literature.

The paper is structured as follows: In the first section, the literature on university reputation is presented. The next section presents methodology, followed by analyses and results. The paper than continues with discussion, concluding remarks, further research suggestions, and limitations.

\section{Theoretical Background}

The most widely used definition of organizational reputation is "a perceptual representation of a company's past actions and future prospects that describes the firm's overall appeal to all of its key constituencies when compared with other leading rivals" (Fombrun, 1996: 72). Brown and Logsdon (1997) indicate that the definition by Fombrun (1996) points the perceptual nature of the construct, describes it as an aggregate perception of all stakeholders, and notes that it is comparative to some standard. Walker (2010) mentions two additional attributes of reputation as well: being positive or negative, being stable and enduring. The author also makes an analysis of all the reputation definitions in the literature and proposes a new definition that differentiates it from two related constructs - organizational identity and corporate image: "a relatively stable, issue specific aggregate perceptual representation of a company's past actions and future prospects compared against some standard" (p. 370). Very recently, Lange et al. (2011) reviewed the literature on organizational reputation literature and identified three conceptualizations of the term: familiarity with the organization, beliefs about what to expect from the organization in the future, and impressions about the organization's favorability.

Thanks to the multidisciplinary richness of reputation research and the multiplicity of definitions, numerous theories are used in both the conceptual and empirical studies to scrutinize organizational reputation (Walker, 2010). Institutional theory is used to shed light on how firms gain legitimacy and cultural support in their institutional envi- 
ronments to develop their reputations (Deephouse and Carter, 2005). Scholars drawing on institutional theory to understand reputation discuss the point that reputation results from information exchanges and social influence among various parties interacting in an organizational context (Rindova and Fombrun, 1999). With a different focus, a signaling theory is used to explain how the strategic choices and actions of firms provide signals, which are then used by different stakeholders to build impressions of the firms (Basdeo et al., 2006). This theory is particularly instrumental in explaining how corporate social performance influences reputation given the preeminence of marketing efforts that highlight company social responsibility (Walker, 2010). The third theory is the resource-based view, which considers reputation as a valuable and rare resource that give rise to sustained competitive advantage. The theory views reputation as a unique resource not only because it is both hard to be imitated and highly causally ambiguous (Deephouse, 2000; Roberts and Dowling, 2002), but also for the reason that it reduces the uncertainty for stakeholders by signaling positive attributes such as product quality (Rindova et al., 2005).

In the education context, as suggested by Kazoleas et al. (2001), universities, like corporations, depend on their images in order to survive and excel in the crowd. Academic reputation, which involves the reputation of the faculty, alumni, quality of the students, post graduate employment opportunities, course variety, student/faculty ratio, reputation for research, male/female ratio, honor programs and advanced placements, are among the major factors affecting students' perceptions (Kealy and Rockel, 1987). Kazoleas et al. (2001), studying the university image from an external stakeholder perspective, found that stakeholders' personal experience with the university or their families' and friends' close relationship with the university influences their perceptions of the university image. Thus, the authors emphasize the importance of the quality of service offered to students, students' parents, administration, staff, and community members.

According to Alessandri (2001), there is a close relationship between the concepts of identity, image, and reputation where corporate identity has an influence on corporate image which than influences corporate reputation. Nguyen and LeBlanc (2001) also studied the individual and interactive effects of institutional image and reputation on students' continuing loyalty to the university. The results of the study suggest that higher perceptions of image and reputation lead to higher levels of loyalty. Melewar and Akel (2005), studying the corporate identity program applied in Warwick University, report that the reputation of the university as an innovative and radical institution is not reflected in the institution's corporate identity system. The authors emphasize the importance of the alignment of the identity with reputation and elaborated on the four major identity components in a university context: communication and visual identity, behavior, corporate culture, and market conditions. If universities can strategically manage and communicate their corporate identity, they can successfully create a competitive advantage (Melewar and Akel, 2005). Van Riel and Balmer (1997) also emphasize the close relationship between corporate identity and reputation. A strong sense of a university visual identity is associated with positive quality perceptions and positive university reputation (Alessandri et al., 2006). 
Sung and Yang (2009) found that active communication and good relationships existing with the students significantly influence their perceptions of its reputation. These then positively affect their support in ways such as making positive references about the university. University reputation is also found to play a significant role in influencing decision-making processes and brand awareness for prospective students (Brewer and Zhao, 2010). Aula and Tienari (2011), adopting a qualitative approach, found that the desire to become a world-class university acts as a significant driving force to legitimize reputation building activities of universities. The study concludes that universities in today's global economy adopt diverse strategic responses to competitive forces (i.e., establishing mergers and acquisitions) and engage in reputation building activities. In a more recent study, Fares et al. (2013) develops a theoretical framework and asserts that service quality, students' satisfaction, and university reputation act as determinants of students' loyalty. Steiner et al. (2013) conceptually analyzing university identity and reputation develops a multidimensional framework. According to the authors, organizational identity which involves structural and cultural dimensions and symbolic identity which involves artifacts and aesthetic impressions refer to more internal dimensions of university identity while reputation which involves public relations and corporate social responsibility are more external. The review suggests that the literature on university reputation is growing with a significant emphasis on understanding diverse actions of universities directed towards building a better reputational status and on evaluating the impact of better reputation on several stakeholder outcomes.

To date, a number of different methods have been utilized in the measurement of organizational reputation. Although the development of a standard measure has been questioned, there seems to be no consensus yet (Schwaiger, 2004; Watson, 2010). Fortune AMAC (America's Most Admired Companies) has been the most popular reputation measure since 1983. The survey respondents are senior executives and outside professionals; the instrument includes ratings of companies on innovativeness, quality of management, long-term investment value, community, environmental responsibility, ability to attract, develop, and keep talented people, quality of products or services, financial soundness, and use of corporate assets (Schwaiger, 2004). The second frequently employed measure is Fombrun et al. (2000) Reputation Quotient (RQ), which consists of 20 items that are grouped under six dimensions (i.e., emotional appeal, products and services, vision and leadership, workplace environment, social and environmental responsibility, and financial performance). Emphasizing the importance of customers as the major stakeholder group, Walsh and Beatty also (2007) developed a customer-based corporate reputation (CBR) measurement under five dimensions of customer orientation, good employer, reliable and financially strong company, product and service quality and social and environmental responsibility.

Since reputation is commonly defined as the overall perception of all the stakeholders in a company, there is a general tendency in most reputation measurement studies to combine the impressions of a company in the minds of its key stakeholder groups (Puncheva-Michelotti and Michelotti, 2010). According to Wartick (2002), the aggregation of the reputation perceptions of different stakeholders inevitably leads to the 
deterioration of the quality of information obtained from these multiple groups surveyed. Similarly, Helm (2007a,b) criticizes such research by pointing to how a company's reputation scores can differ from one another in terms of its customers, employees, and investors. The author notes that different dimensions of the organizational reputation may have different influences on the reputation perceptions of each one of these groups as well. With a similar rationale, Schwaiger (2004) and Helm (2005) introduced formative measures of corporate reputation. In a recent study (i.e., Sarstedt, 2013), convergent and criterion validities of AMAC, RQ, CBR, Schwaiger (2004) and Helm (2005) scales are analyzed and it has been found that all of the five measures of corporate reputation have high levels of discriminant validity although there are differences in terms of convergent and criterion validities. The analysis showed that except for the AMAC index, all the other measures of corporate reputation have high and comparable levels of convergent validity. Yet, in terms of criterion validity, RQ and Schwaiger (2004) performs better that the others.

While most of the reputation studies take corporations as their focus, there is a recent interest in the NPO reputation and its measurement as well. Although research on NPO reputation supports the point that effective reputation management is vital for NPO success, how NPO reputation is going to be measured still remains unanswered (Sarstedt and Schloderer, 2010). Bennett and Gabriel (2003) and Sarstedt and Schloderer (2010) both attempted to develop a scale to evaluate NPO reputation but these two attempts are still in need of further refinement and validation. The Bennett and Gabriel (2003) scale aimed to measure charity image and reputation in the United Kingdom and mostly adapted items from the RQ scale. Sarstedt and Schloderer (2010) conducted a qualitative study and, based on the interview results, developed a scale to measure NPO reputation. According to these authors, NPO reputation dimensions are likeability, competence, quality, performance, organizational social responsibility, and attractiveness.

The review of the university reputation literature shows that there is limited empirical research on the study of university reputation and that there is no consensus on the use of a common scale for reputation measurement. Arpan et al. (2003), studying university reputation, attempt to develop two different measures of university reputation, one from the perspective of students and one from the perspective of non-students. The study was divided in four focus groups that generated the items. According to student data findings, global image rating of a university involved academic rating, athletic rating and news coverage. According to non-student data findings, the rating involved education level, fanship level, and news coverage (Arpan et al., 2003). Alessandri et al. (2006) adopt a revised version of the Fombrun et al. (2000) scale and conceptualize university reputation under the three dimensions of quality of academic performance, quality of external performance, and emotional engagement. In a further study, Yang et al. (2008) used university students' responses and from them conceptualized university reputation under the two dimensions of high quality education and strong sports programs. A more recent study on the conceptualization and measurement of university reputation was conducted by Oktar and Çarıkçı (2012). Adapting the Fombrun et al. (2000) scale the Oktar and Çarıkçı study (2012) analyzed the construct with a multi-stakeholder 
perspective and conceptualized it under the five dimensions of emotional attractiveness, education and service quality, vision and leadership, working environment and social responsibility. Sung and Yang (2009), studying the student-university relationship and reputation, measured university reputation adopting a revised version of the Fombrun et al. (2000) scale. The measure included emotion, university management, perception of media reputation, and perception of academic reputation dimensions. Another recent study (Brewer and Zhao, 2010) measured university reputation by asking respondents about their overall perceptions of the university's leadership, teaching, research, equity, and service.

The above literature review suggests that the material on university reputation is growing. Theoretical and qualitative studies (e.g. Aula and Tienari, 2011; Steiner et al., 2013) concentrate on studying the concept to understand its significance and assessing its contextual relationship with other related variables. The majority of the quantitative studies in the field use revised and adapted versions of the scale developed by Fombrun et al. (2000) (e.g. Alessandri et al, 2006; Sung and Yang, 2009); there are few attempts in the literature regarding conceptualization and measurement of university reputation (e.g. Arpan et al., 2003; Brewer and Zhao, 2010). Accordingly, university reputation literature has yet to develop a valid and a reliable scale, and thus needs further quantitative studies. Considering the increased importance of reputation status both for universities and higher academic institutions, this study attempts to fill this gap.

\section{Methodology}

Churchill (1979) suggests an eight-step procedure for the development of measurement scales that includes item generation, measure purification, and assessment of reliability and validity. This study also adopts Churchill's methodology and uses both qualitative and quantitative research for a better conceptualization of the university reputation construct. First, a thorough literature search defines the domain of the construct (as explained above). Then, as part of the qualitative research, twelve semi-structured indepth interviews are conducted with an aim to generate items for university reputation measurement. Finally, a quantitative study is done which involves three stages. At the first stage, a pre-test is done to purify the items that are generated through the combination of semi-structured interview results and current available scales in the literature in order to check scale reliability. After the scale purification, as the second stage, data are collected from a larger sample and the scale is validated through a confirmatory factor analysis. At the third stage, based on the results of the confirmatory factor analysis a revised version of the scale is developed and distributed to a new sample for revalidation. In addition, a multi-dimensional scaling analysis is also carried out to decide on the universities to be specified on the survey instruments. The details pertaining to all the analyses conducted are explained below. 


\section{Item Generation}

The aim of the qualitative phase of the study is to generate items for university reputation measurement. Sykes (1990) suggests that the sampling procedure in qualitative research is based on purposeful sampling. Accordingly, the participants are selected from different stakeholder groups to assess whether there is any difference in reputational perceptions. With this aim, three major stakeholder groups were identified as 1) students (current and prospective students), staff (both academic and administrative staff), and alumni (university graduates), 2) parents (not university graduates but are parents of university students), and 3) community (neither university graduates nor parents). A heterogeneous representation of each stakeholder group is targeted and twelve semi-structured interviews are conducted. The information related to interviewees is provided in Table 1.

Table 1

Semi-Structured Interview Participants

\begin{tabular}{|c|c|c|c|c|c|}
\hline No & Age & Gender & Education & Occupation & Stakeholder Group \\
\hline 1 & 42 & Male & $\begin{array}{l}\text { Graduate Degree } \\
\text { - Masters }\end{array}$ & $\begin{array}{l}\text { Self-employed in Textile } \\
\text { industry }\end{array}$ & Alumni \\
\hline 2 & 49 & Female & High School & Faculty Secretary & Administrative Staff \\
\hline 3 & 27 & Female & High School & Department Secretary & Administrative Staff \\
\hline 4 & 22 & Female & $\begin{array}{l}\text { Undergraduate Degree } \\
\text { - Enrolled }\end{array}$ & University Student & Current Student \\
\hline 5 & 55 & Male & High School & Retired & Parent \\
\hline 6 & 30 & Female & Graduate Degree - PhD & Research Assistant & Academic Staff \\
\hline 7 & 32 & Female & High School & Housewife & Community \\
\hline 8 & 37 & Female & Graduate Degree - PhD & $\begin{array}{l}\text { Department Head - } \\
\text { Associate Professor }\end{array}$ & Academic Staff \\
\hline 9 & 38 & Male & Graduate Degree - PhD & $\begin{array}{l}\text { Faculty Member - } \\
\text { Assistant Professor }\end{array}$ & Academic Staff \\
\hline 10 & 60 & Female & $\begin{array}{l}\text { Graduate Degree } \\
\text { - Masters }\end{array}$ & Retired & Alumnae \\
\hline 11 & 18 & Male & High School & Student & Prospective Student \\
\hline 12 & 27 & Male & $\begin{array}{l}\text { Graduate Degree } \\
\text { - Enrolled }\end{array}$ & Student & Current Student \\
\hline
\end{tabular}

The interviews are conducted individually because the depth of information is crucial. As suggested by Sykes (1990), individual interviews should be preferred rather than group interviews when different viewpoints are targeted. The interviews are semistructured in the sense that an interview protocol was available but it mostly served as a checklist. In other words, the main general questions are asked and then the subjects are given a chance to describe the concept with their own perceptions of reality. The 
participants are students of, employees of, graduates of different universities, and even those who have not graduated from university but have an awareness about universities as a general public. Therefore, the questions were not specific to a single university but instead were general questions. Sample interview questions included:

1. What is your understanding of reputation in a university concept?

2. Could you please differentiate between a reputable and a non-reputable university?

3. What are the inhibitors/facilitators of reputation in universities?

The interviews are conducted between 1 February-31 March 2013 and an average interview lasts for approximately 45 minutes. All the discussions are both tape-recorded and written down by the interviewers who are the researchers themselves as far as possible in order to ensure a fully detailed understanding of the data. The interviews are ended when saturation is achieved and additional interviews started to generate similar findings. After all the interviews are completed, transcriptions the researchers analyze the content following the procedure adopted by Zimmer and Golden (1988). During the content analysis, all the words and phrases are noted. Among different data analysis methods suggested by Griggs (1987), data reduction is adopted where data is quantified into numbers since the aim is to generate items for university reputation measurement. First, each interview is analyzed individually and then all the results are analyzed in aggregate terms to generate major conclusions. The data has revealed that different stakeholder groups interviewed mentioned similar items which eliminated the possibility of generating different scales for the measurement of different stakeholder perceptions. The complete content analysis results are provided in Table 2.

The interviews aim to generate additional items to add to the reputation scales currently available in the literature (Alessandri et al., 2006; Arpan et al., 2003; Fombrun and van Riel, 1997; Fombrun et al., 2000; Walsh and Beatty, 2007). After the content analysis of the transcriptions, the items generated are compared with the currently available scales. Some of the items repeatedly emphasized by participants are also available in previous research that measures university reputation (see Alessandri et al., 2006 and Arpan et al., 2003). Accordingly after close comparison, 12 items from currently available scales and 12 items that are generated at the end of the content analysis are merged and a 24 item scale is developed. The full scale, including each item with its respective source, is presented in the Appendix.

\section{Pre-testing}

First, a pretest is done with a convenience sample of 94 people by using these 24 items, all measured with five-point Likert scales. In order to avoid any biases resulting from respondents' reliance on different universities as a point of reference, a number of universities that operate for an amount of time sufficient enough for creating awareness, attraction, or familiarity are chosen to be used during data collection. In order to determine these universities, the Times Higher Education World University Rankings (2013) is used. Each year, Times Higher Education evaluates over three thousand universities from several countries worldwide and publishes a list ranking these institutions 
from highest to lowest performers based on six criteria: academic reputation, employer reputation, faculty/student ratio, citations per faculty, international student ratio, and international staff ratio. The list includes only the first 800 universities around the globe with the highest overall assessment. Ten Turkish universities, both state and privately owned universities are included among these 800. In this study, all of these ten Turkish universities are selected and mentioned in the questionnaires, one at a time. However, due to ethical concerns, the university names are replaced by letters.

The pretest sample included the same group of stakeholders (students, academic and administrative staff, alumni, parents and community). Of these 94 people, $55.3 \%$ are female while $44.7 \%$ are male; their average age is 33.6 years. These people are asked to complete the questionnaires and point out any items that they find either ambiguous or difficult to answer.

To assess the reliability of the scale, the Cronbach Alpha value is computed and found as 0.954 , high enough to ensure the usability of the items in an extended study. Item-to-total correlations are all above 0.70 , also signaling high reliability. As a result, no items are eliminated, but a few are reworded to clarify their meanings. To ensure face validity of the proposed scale, the final questionnaire is given to two interviewees that have participated in the qualitative part of the study. These interviewees are asked to examine the items and give feedback. Based on these evaluations, the final version of the survey instrument is developed.

\section{Multi-Dimensional Scaling Analysis}

Before distributing the questionnaire to a wider sample of respondents, a multidimensional scaling analysis is also done to decrease the number of universities to be used during the actual data collection. This process is carried out to decrease the possible discrepancy that may result from the high number universities assessed in the questionnaire. Ten academicians that are knowledgeable about these universities made a pairwise comparison of these entities. Then these comparisons are subjected to a multi-dimensional scaling analysis; these give the optimal perceptual map of objects investigated based on individuals' dissimilarity judgments in a number of solutions of varying dimensionality (Hair et al., 2010). As it is seen in Figure 1, universities are distributed in four different groups in a two- dimensional space. One of the dimensions represents a state versus a privately owned university and the other dimension mostly refers to the engineering and natural sciences versus the social sciences orientation of the institution.

According to Young's stress formula (see Table 3), the biggest improvement is in iteration two. There are substantially smaller improvements in subsequent iterations. This shows that two dimensions are appropriate to get a meaningful representation. As a result, a consumers' four-fold categorization of universities is confirmed. With it, four universities from each one of the quadrants (universities A, C, D, and H) are selected to be specified in the survey instruments (one at a time). 
Table 2

\section{Content Analysis Results of Semi-Structured Interviews}

\begin{tabular}{|c|c|c|c|}
\hline Items/Words/Phrases & Frequency & Items/Words/Phrases & Frequency \\
\hline Reliable/trustworthy & 42 & Qualified top management & 4 \\
\hline High quality academic staff & 36 & $\begin{array}{l}\text { High number of beneficiary } \\
\text { students }\end{array}$ & 3 \\
\hline High quality education & 33 & $\begin{array}{l}\text { A place everybody wants to } \\
\text { work }\end{array}$ & 3 \\
\hline $\begin{array}{l}\text { Preferred/liked/highly selected/ } \\
\text { outshines }\end{array}$ & 25 & $\begin{array}{l}\text { Provides opportunities for } \\
\text { development of academicians }\end{array}$ & 3 \\
\hline Well-established/old & 20 & Committed employees & 3 \\
\hline Respected/accepted & 20 & Valuable & 3 \\
\hline $\begin{array}{l}\text { Has a known and established } \\
\text { name }\end{array}$ & 16 & Innovative/proactive/different & 3 \\
\hline Tough to get into & 16 & No scandals & 3 \\
\hline Financially strong & 15 & $\begin{array}{l}\text { Established internal and } \\
\text { external network }\end{array}$ & 3 \\
\hline Qualified facilities & 14 & $\begin{array}{l}\text { Student center/eases the } \\
\text { university life to students }\end{array}$ & 3 \\
\hline Qualified student profile & 13 & $\begin{array}{l}\text { Alumni association/career day/ } \\
\text { public relations }\end{array}$ & 3 \\
\hline $\begin{array}{l}\text { Successful graduates/strong } \\
\text { alumni }\end{array}$ & 13 & Location & 2 \\
\hline Pays salaries regularly & 12 & Global university & 2 \\
\hline Treats employees fairly & 12 & Stands behind its service & 2 \\
\hline Built over years & 10 & Role model to the society & 2 \\
\hline Successful rector & 8 & Responsive to social issues & 2 \\
\hline Qualified academic research & 8 & Good crisis management & 2 \\
\hline Social impact & 8 & Known academicians & 2 \\
\hline Strong and powerful & 7 & Transparent & 2 \\
\hline $\begin{array}{l}\text { Ease of finding job and } \\
\text { internship opportunities }\end{array}$ & 6 & Provides housing services & 2 \\
\hline Respectful to human being & 6 & Fast & 1 \\
\hline $\begin{array}{l}\text { Festivals/theatres/sports } \\
\text { activities }\end{array}$ & 5 & Big & 1 \\
\hline Campus and campus life & 5 & Ethical & 1 \\
\hline Growth oriented & 4 & Clear & 1 \\
\hline
\end{tabular}


Figure 1

Perceptual Map for the Universities

Derived Stimulus Configuration

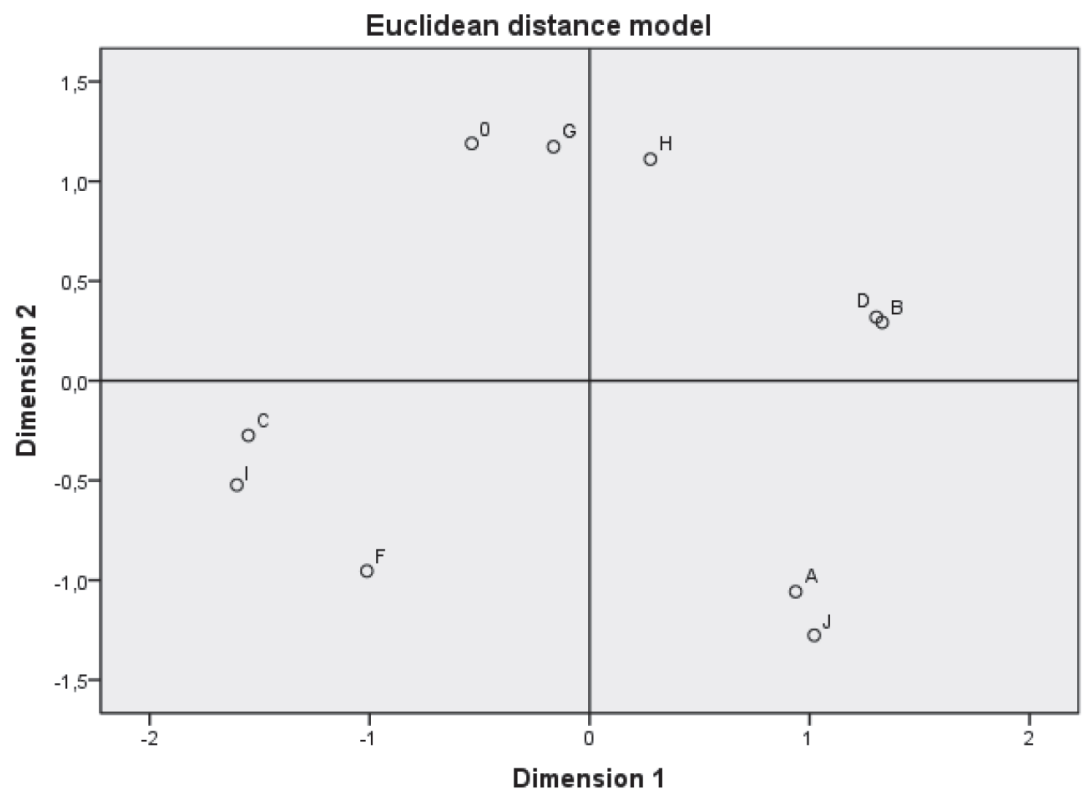

Table 3

Stress Measures for the Multi-Dimensional Solutions

\begin{tabular}{l|l|l}
\hline \multicolumn{4}{l}{ Two-dimensional solution } \\
\hline \multicolumn{3}{l}{ Young's S-stress formula 1 is used. } \\
\hline Iteration & S-stress & Improvement \\
\hline 1 & .44741 & \\
\hline 2 & .41324 & .03417 \\
\hline 3 & .41222 & .00102 \\
\hline 4 & .41329 & -.00107 \\
\hline Iterations stopped because S-stress improvement is less than .001000
\end{tabular}

\section{Data Collection}

Following the pre-test, the scale is distributed to a non-probability sample of 382 students, who are recruited through a convenience sampling technique. This sampling method is chosen in order to reach the students of the faculties that the researchers al- 
ready belong to, thus shortening the data collection period. The participants answered the questionnaires via face-to-face interviews. There are a number of reasons why this data collection mode is selected. First, it allows researchers to clarify the meaning of the individual items included in the scale if respondents find them ambiguous. Second, this method gives the chance of obtaining feedback from the research participants concerning both the content and format of the questionnaires. Third and last, it ensures $100 \%$ completion of the surveys. In addition, freshmen and junior students are targeted since this group has recently passed through a university entrance exam and has evaluated many universities to select the one that best fits their future goals. Hence they hold more up-to-date ideas about the statuses of the universities in question.

The data is collected during May 2014. Out of the 382 surveys, 110 are about university A, 86 about university C, 97 about university D, and 89 about university $\mathrm{H}$. The faculty of management students were $66.2 \% \%$ of the total, and $33.8 \%$ are from the faculty of communication. Females made up $47.3 \%$ and males $52.7 \%$.

\section{Analyses and Results}

\section{Scale Purification}

In order to assess the internal consistency and dimensionality/unidimensionality of the items in this study, both a reliability test and an exploratory factor analysis (EFA) are conducted (Gerbing and Anderson, 1988). The 24 items measuring the university reputation construct have a high internal consistency, reflected by a Cronbach's alpha estimate of .96. Since all the item-to-total correlations are above the recommended level of .70, thus indicating internal consistency (Nunnally and Bernstein, 1978), no items are deleted at this stage.

Gerbing and Anderson (1988) mention the importance of EFA to purify multiple indicators of a construct for a manageable set of items. Therefore, EFA is conducted using a Principal Component Analysis (PCA) with Varimax rotation procedure in order to identify the factor structure of the scale. The Bartlett's Test of Sphericity is significant and the Kaiser-Meyer-Olkin (MSA) estimate for the data set is .96, indicating that the use of factor analysis is appropriate. The analysis generated three significant factors based on the criterion of eigenvalue greater than one. These factors are named as academic competence, responsible management, and social attractiveness and, in total, account for $62 \%$ of the total variance explained in the data. Finally, four items with low cross-loadings and/or loading on multiple dimensions are eliminated from the scale and the remaining 20-item scale has a Cronbach's alpha estimate of .95. See Table 4 for the results of EFA. 
Table 4

EFA Results for the 24 Item University Reputation Scale

\begin{tabular}{|c|c|c|c|c|}
\hline & & \multicolumn{3}{|c|}{ Factor Loadings } \\
\hline Item No & Item & Dimension 1 & Dimension 2 & Dimension 3 \\
\hline Item16 & The university is a respected university. & .812 & & \\
\hline Item 15 & $\begin{array}{l}\text { The university is a well-established } \\
\text { university. }\end{array}$ & .802 & & \\
\hline Item17 & The university is a well-known university. & .802 & & \\
\hline Item 18 & The university has successful alumni. & .772 & & \\
\hline Item 14 & The university is a highly preferred university. & .719 & & \\
\hline Item 2 & $\begin{array}{l}\text { The university has an outstanding student } \\
\text { profile. }\end{array}$ & .650 & & \\
\hline Item 1 & The university offers high quality education. & .649 & & \\
\hline Item 9 & $\begin{array}{l}\text { The university has nationally known } \\
\text { academic programs/departments/schools. }\end{array}$ & .583 & & \\
\hline Item 12 & This university is a reliable university. & .574 & & \\
\hline Item 3 & The university has high quality faculty. & .561 & & \\
\hline Item 4 & $\begin{array}{l}\text { The university has nationally known } \\
\text { professors. }\end{array}$ & .484 & & .470 (deleted) \\
\hline Item 11 & $\begin{array}{l}\text { The university is committed to academic } \\
\text { excellence. }\end{array}$ & .445 & .429 & .412 (deleted) \\
\hline Item 21 & $\begin{array}{l}\text { This university's graduates can easily get } \\
\text { employed. }\end{array}$ & .412 & & \\
\hline Item 10 & $\begin{array}{l}\text { The university has good resources for } \\
\text { students (computer equipment, library, } \\
\text { transportation, etc.). }\end{array}$ & & .765 & \\
\hline Item 24 & The university is an innovative university. & & .725 & \\
\hline Item 13 & $\begin{array}{l}\text { The university offers many good cultural } \\
\text { experiences. }\end{array}$ & & .685 & \\
\hline Item 23 & $\begin{array}{l}\text { The university is an institution where both } \\
\text { academic and administrative staff would like } \\
\text { to work. }\end{array}$ & & 672 & \\
\hline Item 22 & The university has a good campus. & & .609 & \\
\hline Item 6 & $\begin{array}{l}\text { The university looks like a university with } \\
\text { strong prospects for future growth. }\end{array}$ & & .567 & \\
\hline Item 19 & $\begin{array}{l}\text { The university treats its employees well and } \\
\text { fairly. }\end{array}$ & & & .715 \\
\hline Item 20 & The university has a successful rector. & & & .688 \\
\hline Item 8 & $\begin{array}{l}\text { The university is a responsible member of the } \\
\text { community. }\end{array}$ & & & .515 \\
\hline Item 7 & $\begin{array}{l}\text { The media reports of the university are in } \\
\text { general positive. }\end{array}$ & .416 & & .492 (deleted) \\
\hline Item 5 & The university is tough to get into. & .478 & & .488 (deleted) \\
\hline
\end{tabular}

Total variance explained $=62 \%$

Kaiser-Meyer-Olkin Measure of Sampling Adequacy $=.96$

Significance of Bartlett's Test of Sphericity $=.00$ 


\section{Scale Validation}

As the next step, a confirmatory factor analysis (CFA) is conducted to further assess the dimensionality, reliability, and validity of the purified measures. Twenty items measuring university reputation are hypothesized to load on three dimensions that emerged as a result of EFA (see Figure 2).

Figure 2

\section{Measurement Model}

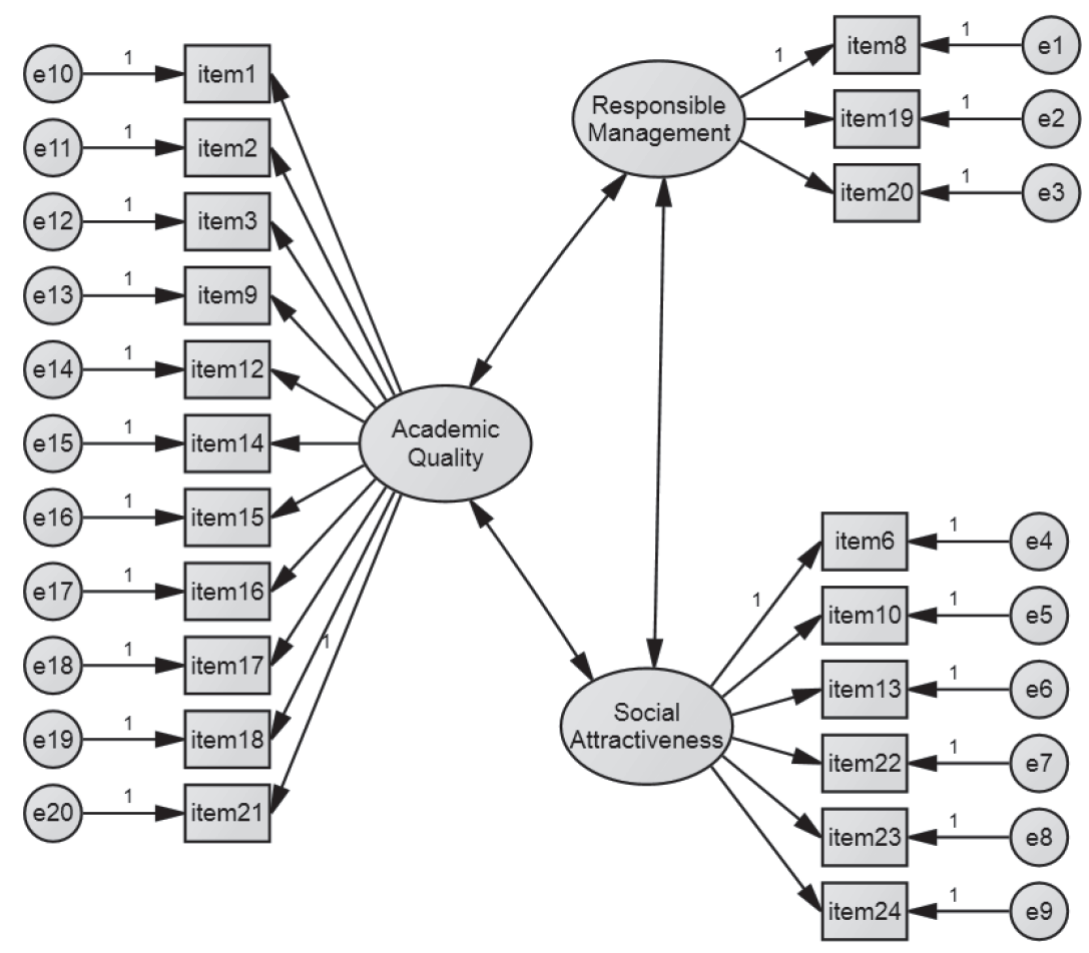

This three-factor model produced the significant chi-square statistic $\left[\chi_{(167)}^{2}=594\right]$ as expected due to the large sample size. In addition, although the GOF indices signal that the observed and estimated covariance matrices fit well [comparative fit index $(\mathrm{CFI})=.92$; normed fit index $(\mathrm{NFI})=.89$; root mean square error of approximation $($ RMSEA $)=.08]$, two items are dropped out of the study due to their low standardized loadings. When the GOF indices of the new measurement model is examined, it is seen that the chi-square test is still significant, but the other fit measures are at acceptable limits $[\mathrm{CFI}=.93 ; \mathrm{NFI}=.90 ; \mathrm{RMSEA}=.08]$ and the remaining eighteen university reputation items have standardized loadings significant at a $p$ value of .01 (see Table 5). 
Table 5

Standardized Item Loadings for Measures of University Reputation

\begin{tabular}{|c|c|c|c|}
\hline $\begin{array}{l}\text { Item } \\
\text { No }\end{array}$ & Item & Dimension & $\begin{array}{l}\text { Standardized } \\
\text { Loadings }\end{array}$ \\
\hline Item 1 & The university offers high quality education. & $\begin{array}{l}\text { Academic } \\
\text { competence }\end{array}$ & $.80 * * *$ \\
\hline Item 2 & The university has an outstanding student profile. & & Deleted in CFA \\
\hline Item 3 & The university has high quality faculty. & $\begin{array}{l}\text { Academic } \\
\text { competence }\end{array}$ & $.74 * * *$ \\
\hline Item 4 & The university has nationally known professors. & & Deleted in EFA \\
\hline Item 5 & The university is tough to get into. & & Deleted in EFA \\
\hline Item 6 & $\begin{array}{l}\text { The university looks like a university with strong } \\
\text { prospects for future growth. }\end{array}$ & $\begin{array}{l}\text { Social } \\
\text { attractiveness }\end{array}$ & $.74 * * *$ \\
\hline Item 7 & $\begin{array}{l}\text { The media reports of the university are in general } \\
\text { positive. }\end{array}$ & & Deleted in EFA \\
\hline Item 8 & $\begin{array}{l}\text { The university is a responsible member of the } \\
\text { community. }\end{array}$ & $\begin{array}{l}\text { Responsible } \\
\text { management }\end{array}$ & $.76^{* * *}$ \\
\hline Item 9 & $\begin{array}{l}\text { The university has nationally known academic programs/ } \\
\text { departments/schools. }\end{array}$ & $\begin{array}{l}\text { Academic } \\
\text { competence }\end{array}$ & $.78 * * *$ \\
\hline Item 10 & $\begin{array}{l}\text { The university has good resources for students (computer } \\
\text { equipment, library, transportation, etc.). }\end{array}$ & $\begin{array}{l}\text { Social } \\
\text { attractiveness }\end{array}$ & $.71^{* * *}$ \\
\hline Item 11 & The university is committed to academic excellence. & & Deleted in EFA \\
\hline Item 12 & This university is a reliable university. & $\begin{array}{l}\text { Academic } \\
\text { competence }\end{array}$ & $.78 * * *$ \\
\hline Item 13 & The university offers many good cultural experiences. & $\begin{array}{l}\text { Social } \\
\text { attractiveness }\end{array}$ & $.71^{* * *}$ \\
\hline Item 14 & The university is a highly preferred university. & $\begin{array}{l}\text { Academic } \\
\text { competence }\end{array}$ & $.78 * * *$ \\
\hline Item 15 & The university is a well-established university. & $\begin{array}{l}\text { Academic } \\
\text { competence }\end{array}$ & $.83 * * *$ \\
\hline Item16 & The university is a respected university. & $\begin{array}{l}\text { Academic } \\
\text { competence }\end{array}$ & $.89 * * *$ \\
\hline Item17 & The university is a well-known university. & $\begin{array}{l}\text { Academic } \\
\text { competence }\end{array}$ & $.87 * * *$ \\
\hline Item 18 & The university has successful alumni. & $\begin{array}{l}\text { Academic } \\
\text { competence }\end{array}$ & $.80 * * *$ \\
\hline Item 19 & The university treats its employees well and fairly, & $\begin{array}{l}\text { Responsible } \\
\text { management }\end{array}$ & $.64 * * *$ \\
\hline Item 20 & The university has a successful rector. & $\begin{array}{l}\text { Responsible } \\
\text { management }\end{array}$ & $.66^{* * *}$ \\
\hline Item 21 & This university's graduates can easily get employed. & & Deleted in CFA \\
\hline Item 22 & The university has a good campus. & $\begin{array}{l}\text { Social } \\
\text { attractiveness }\end{array}$ & $.75^{* * *}$ \\
\hline Item 23 & $\begin{array}{l}\text { The university is an institution where both academic and } \\
\text { administrative staff would like to work. }\end{array}$ & $\begin{array}{l}\text { Social } \\
\text { attractiveness }\end{array}$ & $.74 * * *$ \\
\hline Item 24 & The university is an innovative university. & $\begin{array}{l}\text { Social } \\
\text { attractiveness }\end{array}$ & $.73^{* * *}$ \\
\hline
\end{tabular}


The aim of conducting the CFA is to assess the validity of the measurement model, which reflects the extent to which observed variables accurately measure what they are supposed to (Cook and Campbell, 1979). Construct validity is assessed through both convergent and discriminant validities of the measurement scales. While convergent validity examines the similarity between related constructs, discriminant validity looks for "a divergence between measures of related but conceptually different things" (Cook and Campbell, 1979, p. 61).

Convergent validity of the measurement scale for university reputation is ensured by significant loadings of all items on their respective dimensions, with lowest $t$-value being 10.74. Since average variance extracted (AVE) for each dimension included in the measurement model test is greater than its squared correlations with other dimensions (Fornell and Larcker, 1981), a discriminant validity of the measurement model is obtained as well (see Table 6).

Table 6

Descriptive Statistics for Dimensions and Dimension Correlations

\begin{tabular}{l|c|c|c|c|c|c}
\hline & AVE & Mean & S.D. & $\mathbf{1}$ & $\mathbf{2}$ & $\mathbf{3}$ \\
\hline Academic competence & .92 & 3.94 & .86 & .94 & & \\
\hline Responsible management & .89 & 3.38 & .71 & $.60 * *$ & .95 & \\
\hline Social attractiveness & .90 & 3.62 & .84 & $.75^{* *}$ & $.62 * *$ & .87 \\
\hline
\end{tabular}

Note: Values on the diagonal are Cronbach's alpha estimates.

$* * p<.01$ (one-tailed tests).

$* p<.05$ (one-tailed tests).

According to Churchill (1979), reliability and validity of a newly developed scale should also be assessed with new data. Therefore the purified scale including 18 items are distributed to a new sample and 265 usable questionnaires are collected from students of three different private universities in Istanbul via face-to-face interviews. The reason why three universities are selected to collect data is to increase the generalizability of the study's finding through a more representative sample of the largest stakeholder group, the students. However, different from the first data collection period, these students interviewed are at both undergraduate and graduate levels. Graduate students are also included in the new sample to ensure multiplicity of opinions since graduate level participants bring in greater experience and knowledge. The data collection lasted for two weeks during November 2014. The faculty of management was represented by $74 \%$; whereas $24 \%$ are from the faculty of communication. Of these, $43.3 \%$ are female and $52.7 \%$ are male.

Similar to the procedure followed in scale purification, reliability is checked first via Cronbach's alpha estimate and found as .94 with all the item-to-total correlations above the recommended level of .70 (Nunnally and Bernstein, 1978). In addition, the reliability statistics for the three dimensions of academic competence, social attractiveness, and responsible management are $.95, .91$, and .79 respectively. 
Then, a CFA is conducted for the assessment of construct validity. The 18 items measuring university reputation are hypothesized to load on three dimensions that were validated in the previous part. Again, the three-factor model produced a significant chisquare statistic $\left[\chi_{(132)}^{2}=562\right]$. The GOF indices are at acceptable limits [comparative fit index $(\mathrm{CFI})=.90$; normed fit index $(\mathrm{NFI})=.89$; root mean square error of approximation $($ RMSEA $)=.11]$. All the eighteen university reputation items have standardized loadings significant at a $p$ value of .01 as well.

Overall, 18 items classified into three dimensions are found to be reliable and valid measures of university reputation. After analyzing the item structure and by referring back to the literature these factors are named as academic competence, social attractiveness, and responsible management.

When the items classified into each dimension are analyzed in detail it can be concluded that academic competence refers to education quality and general competence of the university. This dimension has correspondence with the products and services dimension in RQ (reputation quotient) (Fombrun et al., 2000), which includes items referring to the quality and attractiveness of the products and services offered by companies. Academic competence includes not only the items that indicate the quality of the service provided by the university (which is actually the education) but also the items that reflect general competence of the university (i.e. well-established university). Similar items were also found in Sarstedt and Schloderer (2010)'s study and categorized under the dimension of competence. Accordingly, academic competence of universities involves both the current quality of educational system established in the institution and the enduring strong positive impressions among the society.

Social attractiveness involves items that refer to innovative capacity of the university together with its physical conditions and social attractiveness. This dimension of university reputation scale is the one that mostly differentiates it from other corporate reputation measures. Universities should be institutions where students, employees and sometimes even the general public find opportunities to participate in cultural and social events. Similar items were also mentioned by Arpan et al. (2003) under the academic dimension. Responsible management dimension involves the responsibilities of the university management to external stakeholders and to its employees. Social responsibility programs carried out by universities have been a major topic of discussion in the corporate social responsibility literature (Hill, 2004; Van Weenen, 2000). According to Atakan and Eker (2007) universities may engage in corporate social responsibility programs as part of their corporate image construction and therefore those are crucial for their reputational status.

\section{Discussion and Conclusion}

Reputation is becoming one of the most critical elements that universities, like many other institutions, have to respond to, especially in today's dual national and global context that is characterized by increasing investments in the higher education industry. The significance and richness of the reputation construct have triggered many researchers 
to investigate the construct from different theoretical perspectives so far. Institutional theory (e.g., Deephouse and Carter, 2005), signaling theory (e.g., Basdeo et al., 2006), and the resource-based view (e.g., Deephouse, 2000) are the three most frequently used theoretical bases that are embodied in reputation research, either at corporate or NPO levels. While there are many other theories that have been used to explain the importance of reputation to stakeholders as well, all of them approach the issue from a different angle and make the development of a unified understanding of the concept extremely difficult (Walker, 2010). On the other hand, while the technologically connected world where information travels so fast and has a global impact can foster the development of reputation across regions easily, it may have adverse effects as well if the institutions do not put enough efforts in activities that build a good reputation.

The rapid increase in the number of universities both in the global and national context also intensifies the reputational concerns of universities. Newly established ones aspire to attract qualified academicians and talented students and thereby are under great competitive pressure. On the other hand, established and old universities also seek to continuously innovate and improve themselves so as not to fall behind the competition. Another issue is the difference between public and private universities, especially in the national context of the current study. According to YOK (2012) as of March 2013 there are 104 public and 74 private universities in Turkey. According to Atakan and Eker (2007), while educational resources of the public universities are less than the private ones, most of them are still ranked among the top tier of universities in the country. In such a fierce competition, the efforts especially of young private universities to attract prestigious academicians and provide exceptional social and physical opportunities to students have been inevitably increased. However, despite the importance of reputation for universities in attracting the best academicians and students as well as funding, how the concept is going to be measured is still ambiguous.

Accordingly, the current study attempts to develop and validate a scale of reputation measurement for universities and the general public to assess the reputational status of these higher education institutions that have diverse sets of qualifications. The main contribution of the study is that it offers a broadened understanding of university reputation as a multidimensional construct by developing a psychometrically robust measure. The study, through conducting a number of studies with a range of methodologies, reports that university reputation is a theoretically and managerially relevant construct, and that the scale has an acceptable reliability and validity. Empirical findings are in support of the convergent and discriminant validity of the proposed university reputation scale. The 18 items included in the final measurement instrument represent three interrelated first order factors referred to as academic competence, social attractiveness, and responsible management; these correspond with a higher order university reputation construct. This result is validated across multiple samples as well.

The scale is valuable in the sense that it allows both researchers and university management to explore how reputation perceptions of different stakeholders are formed and gives the chance to take strategic actions regarding the development and management of reputation. With the given intensity of competition, reputation can be an important 
positioning device. Demonstrating that reputation is central to the university through communicating its quality of education as well as academic competence of its students and faculty, mentioning what makes the university a socially attractive entity, and providing evidence as to its environmentally and socially responsible management philosophy can insure a successful market position.

When provided the ability to evaluate reputation perceptions of multiple stakeholders, those in charge of university management will be empowered to improve their value creation processes; these will, in turn, contribute to greater loyalty and attachment to the institution. Better reputation assessments will undoubtfully be influential in creating student and faculty satisfaction as well as academic, financial and managerial performance, and will be a continuing enhancement.

The scale developed in this study will also enable the reputational status of universities to be tracked over time. As a result, management will have the opportunity to track the institutions' strengths and weaknesses continuously and understand how fast these are communicated to all the stakeholder groups and how they affect their reputational perceptions. Such knowledge can inform the direction of future communication strategies as well, thus playing a crucial role in the establishment of competitive positioning.

To sum up, the proposed university reputation scale developed indicates that the reputational status of universities and of general higher education institutions depends on their performance in academic competence, social attractiveness and responsible management. According to the findings of this study reputable universities have 1) high academic quality, 2) are well-established and recognized, 3) are innovative and offering several physical and social advancement opportunities, 4) are managed by a successful rector and 5) are responsible to its external and internal stakeholders including the environment.

\section{Limitations and Future Research Suggestions}

A number of limitations should be taken into account while evaluating the findings and implications of this study in which, twelve interviews are held to generate items. Future research with a more extensive qualitative study including a number of focus groups each with a different stakeholder group may lead to greater diversity and richness in the resulting scale. Second, the data used to validate the items have been collected from only one of the main stakeholders: students. A larger sample with equal representation of all the stakeholders (alumni, academics, parents, etc.) might improve the external validity of the scale developed. Even more specifically, this sample consists of only students from the faculties of management and communication. However, the multidimensional scaling analysis conducted in this study to select universities to be mentioned on the questionnaires shows that "engineering versus natural sciences orientation" is one dimension that different stakeholders base their comparisons of universities on. Therefore, future researchers are urged to replicate this effort by including students from a diverse set of faculties. Third, the four universities used as points of reference during the data collection process are all from the most reputable universities list published by Times 
Higher Education each year. The question of whether the results would be similar or not if less reputable universities are mentioned on survey instruments still remains unanswered. Thus, future research on this issue is recommended in order to collect data over a wider range of universities.

The questionnaire used in this study included only the proposed university reputation scale. However, if measures of related constructs are given a place in the survey instrument, it might be possible to test the newly offered university reputation scale's nomological validity. Furthermore, this research has been carried out in one cultural context; but re-test of the proposed scale in different cultural settings may improve its external generalizability. In a similar vein, how different dimensions of the university reputation vary across different times and contexts important questions to be resolved. Future researchers might also focus on the dimensionalization of the construct through longitudinal research designs and under differing conditions.

\section{References}

Abimbola, T. and Vallester, C. (2007). "Brand, Organizational Identity and Reputation in SMEs: An Overview," Qualitative Market Research, 10(4): 341-348.

Alessandri, S.W. (2001). "Modeling Corporate Identity: A Concept Explication and Theoretical Explanation," Corporate Communication: An International Journal, 6(4): 173-182.

Alessandri, S.W., Yang, S., and Kinsey D.F. (2006). "An Integrative Approach to University Visual Identity and Reputation," Corporate Reputation Review, 9(4): 258-270.

Arpan, L.M., Raney, A.A., and Zivnuska, S. (2003). "A Cognitive Approach to Understanding University Image," Corporate Communications: An International Journal, 8(2): 97-113.

Atakan, S.M.G. and Eker, T., (2007). "Corporate Identity of a Socially Responsible University: A Case from the Turkish Higher Education Sector," Journal of Business Ethics, 76: 55-68.

Aula, H. and Tienari, J. (2011). "Becoming 'World-Class'? Reputation-building in a University Merger, "Critical Perspectives on International Business, 7(1):7-29.

Basdeo, D.K., Smith, K.G., Grimm, C.M., Rindova, V.P., and Derfus, P.J. (2006). "The Impact of Market Actions on Firm Reputation,” Strategic Management Journal, 27: 1205-1219.

Bennett, R. and Gabriel, H. (2003). "Image and Reputational Characteristics of UK Charitable Organizations: An Empirical Study," Corporate Reputation Review, 6(3): 276-289.

Brewer, A. and Zhao, J., (2010). "The Impact of a Pathway College on Reputation and Brand Awareness for its Affiliated University in Sydney," International Journal of Educational Management, 24(1): 34-47.

Brown, B., and Logsdon, J.M. (1997). "Factors Influencing Fortune's Corporate Reputation for Community and Environmental Responsibility," in J. Weber and K. Rehbein, (eds.), IABS Proceedings (Tenth Annual Conference): 168-173. Paris: International Association for Business and Society.

Brown, E. and Slivinski, A. (2006). "Nonprofit Organizations and the Market," in W.W. Powell and R. Steinberg (eds.), The Non-Profit Sector. A Research Handbook: 140-158. New Haven, London: Yale University Press.

Bowman, N.A. and Bastedo, M.N. (2011). "Anchoring Effects in World University Rankings: Exploring Biases in Reputation Scores," Higher Education, 61: 431-444. 
Churchill, G.A. (1979). "A Paradigm for Developing Better Measures of Marketing Constructs," Journal of Marketing Research, 64-73.

Cook, T.D. and Campbell, D.T. (1979). Quasi Experimentation: Design and Analytical Issues for Field Settings. Chicago, Rand McNally.

Deephouse, D.L. and Carter, S.M. (2005). “An Examination of Differences between Organizational Legitimacy and Organizational Reputation," Journal of Management Studies, 42(2): 329-360.

Deephouse, D.L. (2000). "Media Reputation as a Strategic Resource: An integration of Mass Communication and Resource-Based Theories," Journal of Management, 26(6): 1091-1112.

Fares, D., Achour, M., and Kachkar, O. (2013). "The Impact of Service Quality, Student Satisfaction, and University Reputation on Student Loyalty: A Case Study on International Students in IIUM, Malaysia," Information Management and Business Review, 5(12): 584-590.

Fombrun, C., Gardberg, N.A., and Sever, J.M. (2000). "The Reputation Quotient: A Multi-Stakeholder Measure of Corporate Reputation," Journal of Brand Management, 7(4): 241-255.

Fombrun, C.J. and van Riel, C.B.M. (1997). "The Reputational Landscape," Corporate Reputation Review, 1(1/2): 5-13.

Fombrun, C.J. (1996). Reputation: Realizing Value from the Corporate Image. Boston, MA: Harvard Business School Press.

Fornell, C. and Larcker, D.F. (1981). "Evaluating Structural Equation Models with Unobservable Variables and Measurement Error," Journal of Marketing Research, 18(1): 39-50.

Galaskiewicz, J. and Colman, M.S. (2006). "Collaboration between Corporations and Nonprofit Organizations," in W.W. Powell and R. Steinberg (eds.), The Non-Profit Sector. A Research Handbook: 180-204. New Haven, London: Yale University Press.

Gardberg, N.A. and Fombrun, C.J. (2002). "The Global Reputation Quotient Project: First Steps Towards a Cross-nationally Valid Measure of Corporate Reputation," Corporate Reputation Review, 4(4): 303-307.

Gerbing, D.W. (1988). "An Updated Paradigm for Scale Development Incorporating Unidimensionality and its Assessment," Journal of Marketing Research, 25: 186-192.

Griggs, S. (1987). “Analysing Qualitative Data,” Journal of the Market Research Society, 29(1): 15-34.

Gotsi, M. and Wilson, A.M. (2001). "Corporate Reputation Management: Living the Brand," Management Decision, 39(2): 99-104.

Hair, J.F., Black, W.C., Babin, B.J., and Anderson, R.E. (2010). Multivariate Data Analysis: A Global Perspective. Upper Saddle River, New Jersey, NJ: Pearson Prentice Hall.

Hall, R. (1993). "A Framework Linking Intangible Resources and Capabilities to a Sustainable Advantage,” Strategic Management Journal, 14(8): 607-618.

Helm, S. (2005). "Designing a Formative Measure for Corporate Reputation," Corporate Reputation Review, 8(2): 95-109.

------, (2007a). “One Reputation or Many? Comparing Stakeholders' Perceptions of Corporate Reputation,” Corporate Communications: An International Journal, 12(3): 238-254.

------, (2007b). "The Role of Corporate Reputation in Determining Investor Satisfaction and Loyalty," Corporate Reputation Review, 10(1): 22-37.

Hill, R.P. (2004). "The Socially Responsible University: Talking the Talk while Walking the Walk in the College of Business," Journal of Academic Ethics, 2: 89-100. 
Kay, J. (1993). Foundations of Corporate Success. Oxford: Oxford University Press.

Kazoleas, D., Kim, Y., and Moffitt, M.A. (2001). "Institutional Image: A Case Study," Corporate Communications: An International Journal, 6(4): 205-216.

Kealy, M.J. and Rockel, M.L., (1987). "Student Perceptions of College Quality: The Influence of College Recruitment Policies," The Journal of Higher Education, 58(6): 683-703.

Lange, D., Lee, P.M., and Dai, Y. (2011). “Organizational Reputation: A Review," Journal of Management, 37(1): 153-184.

Leete, L. (2006). "Work in the Nonprofit Sector," in W.W. Powell and R. Steinberg (eds.), The NonProfit Sector. A Research Handbook: 159-179. New Haven, London: Yale University Press.

Lowly, R.C. and Silver, B.D. (1996). “A Rising Tide Lifts all Boats: Political Science

Department Reputation and the Reputation of the University," Political Science and Politics, 29(2): 161-167.

Melewar, T.C. and Akel, S. (2005). "The Role of Corporate Identity in the Higher Education Sector: A Case Study," Corporate Communications: An International Journal, 10(1): 41-57.

Nguyen, N. and LeBlanc, G. (2001). "Image and Reputation of Higher Education Institutions in

Students' Retention Decisions," The International Journal of Educational Management, 15(6): 303-311.

Nunnally, J. and Bernstein, I.H. (1994). Psychometric Theory. New York: McGraw-Hill. Oktar, O.F. and Çarıkçı, I.H. (2012). "In Terms of the Different Stakeholders' Perceptions of

University Reputation: An Investigation in Süleyman Demirel University," Journal of Süleyman Demirel University Institute of Social Sciences, 1(15): 127-149.

Puncheva-Michelotti, P. and Michelotti, M. (2010). "The Role of the Stakeholder Perspective in Measuring Corporate Reputation," Marketing Intelligence and Planning, 28(3): 249-274.

Ressler, J. and Abratt, R. (2009). “Assessing the Impact of University Reputation on Stakeholder Intentions," Journal of General Management, 35(1): 35-45.

Rindova, V.P., Williamson, I.O., Petkova, A.P., and Sever, J.M. (2005). "Being Good or Being

Known: An Empirical Examination of the Dimensions, Antecedents, and Consequences of Organizational Reputation," Academy of Management Journal, 48(6): 1033-1049.

Rindova, V.P. and Fombrun, C.J. (1999). "Constructing Competitive Advantage: The Role of Firmconstituent Interactions," Strategic Management Journal, 20(8): 691-710.

Roberts, P.W. and Dowling, G.R. (2002). "Corporate Reputation and Sustained Superior Financial Performance," Strategic Management Journal, 23(12): 1077-1093.

Sarstedt, M. and Schloderer, M.P. (2010). "Developing a Measurement Approach for Reputation of Non-profit Organizations," International Journal of Nonprofit and Voluntary Sector Marketing, 15: 276-299.

Sarstedt, M., Wilczynski, P., and Melewar, T.C. (2013). "Measuring Reputation in Global Markets: A Comparison of Reputation Measures' Convergent and Criterion Validities," Journal of World Business, 48: 329-339.

Schwaiger, M. (2004). "Components and Parameters of Corporate Reputation - An Empirical Study," Schmalenbach Business Review, 56: 46-71.

Smith, D. and Shen, C. (1996). "Factors Characterizing the Most Effective Nonprofits Managed by Volunteers," Nonprofit Management and Leadership, 6(3): 271-289. 
Steiner, L., Sundström, A.C., and Sammalisto, K. (2013). “An Analytical Model for University Identity and Reputation Strategy Work," Higher Education, 65: 401-415.

Sung, M. and Yang, S. (2008). "Toward the Model of University Image: The Influence of Brand Personality, External Prestige, and Reputation," Journal of Public Relations Research, 20(4):

357-376.

------, (2009). "Student-University Relationships and Reputation: A Study of the Links between Key Factors Fostering Students' Supportive Behavioral Intentions toward their University,"

Higher Education, 57: 787-811.

Sykes, W. (1990). "Validity and Reliability in Qualitative Market Research: A Review of the Literature," Journal of the Market Research Society, 32(3): 289-327.

Theus, K.T. (1993). “Academic Reputations: The Process of Formation and Decay,” Public Relations Review, 19(3): 277-291.

Van Riel, C.B.M. and Balmer, J.M.T. (1997). "Corporate Identity: The Concept, its Measurement and Management," European Journal of Marketing, 31(5/6): 340-356.

Van Weenen, H. (2000). “Towards a Vision of a Sustainable University," International Journal of Sustainability in Higher Education, 1(1): 20-34.

Venable, B.T., Rose, G.M., Bush, V.D., and Gilbert F.W. (2005). “The Role of Brand

Personality in Charitable Giving: An Assessment and Validation," Journal of the Academy of Marketing Science, 33(3): 295-312.

Walker, K. (2010). “A Systematic Review of the Corporate Reputation Literature: Definition, Measurement, and Theory," Corporate Reputation Review, 12(4): 357-387.

Walsh, G. and Beatty, S.E. (2007). "Customer-based Corporate Reputation of a Service Firm: Scale Development and Validation," Journal of the Academy of Marketing Science, 35: 127-143.

Wartick, S.L. (2002). "Measuring Corporate Reputation: Definition and Data," Business and Society, 41(4): 371-392.

Watson, T. (2010). "Reputation Models, Drivers and Measurement," in Heath, R.L. (ed.) Sage Handbook of Public Relations: 339-352. London: Sage.

Weerawardena, J. and Mort, G.S. (2008). "Nonprofit Competitive Strategy," International Journal of Nonprofit and Voluntary Sector Marketing, 13(2): 103-106.

Yang, S., Alessandri, S.W., and Kinsey D.F. (2008). "An Integrative Analysis of Reputation and Relational Quality: A Study of University-Student Relationships," Journal of Marketing for Higher Education, 18(2): 145-170.

Times Higher Education (TME) World University Rankings (2013). Retrieved from http://www.topuniversities.com/university-rankings/world-university-rankings/2013\#sorting=rank+ region $=+$ country $=134+$ faculty $=+$ stars $=$ false + search $=$

YÖK (2012). Yüksekögretim Kurumu Faaliyet Raporu (Activities Report of the Council of Higher Education), Council of Higher Education, Ankara.

Zimmer, M. R. and Golden, L.L., (1988). "Impressions of Retail Stores: A Content Analysis of Consumer Images,” Journal of. Retailing, 64 (3): 265-293. 


\section{APPENDIX}

\section{The University Reputation Scale}

\begin{tabular}{|c|c|c|}
\hline Item 1 & The university offers high quality education. & Alessandri et al., 2006 \\
\hline Item 2 & The university has an outstanding student profile. & Alessandri et al., 2006 \\
\hline Item 3 & The university has high quality faculty. & Alessandri et al., 2006 \\
\hline Item 4 & The university has nationally known professors. & Arpan et al., 2003 \\
\hline Item 5 & The university is tough to get into. & Arpan et al., 2003 \\
\hline Item 6 & $\begin{array}{l}\text { The university looks like a university with strong prospects } \\
\text { for future growth. }\end{array}$ & Alessandri et al., 2006 \\
\hline Item 7 & The media reports of the university are in general positive. & Alessandri et al., 2006 \\
\hline Item 8 & The university is a responsible member of the community. & Alessandri et al., 2006 \\
\hline Item 9 & $\begin{array}{l}\text { The university has nationally known academic programs/ } \\
\text { departments/schools. }\end{array}$ & Arpan et al., 2003 \\
\hline Item 10 & $\begin{array}{l}\text { The university has good resources for students (computer } \\
\text { equipment, library, transportation, etc.). }\end{array}$ & Arpan et al., 2003 \\
\hline Item 11 & The university is committed to academic excellence. & Arpan et al., 2003 \\
\hline Item 12 & This university is a reliable university. & Current study \\
\hline Item 13 & The university offers many good cultural experiences. & Arpan et al., 2003 \\
\hline Item 14 & The university is a highly preferred university. & Current study \\
\hline Item 15 & The university is a well-established university. & Current study \\
\hline Item 16 & The university is a respected university. & Current study \\
\hline Item17 & The university is a well-known university. & Current study \\
\hline Item 18 & The university has successful alumni. & Current study \\
\hline Item 19 & The university treats its employees well and fairly. & Current study \\
\hline Item 20 & The university has a successful rector. & Current study \\
\hline Item 21 & This university's graduates can easily get employed. & Current study \\
\hline Item 22 & The university has a good campus. & Current study \\
\hline Item 23 & $\begin{array}{l}\text { The university is an institution where both academic and } \\
\text { administrative staff would like to work. }\end{array}$ & Current study \\
\hline Item 24 & The university is an innovative university. & Current study \\
\hline
\end{tabular}


